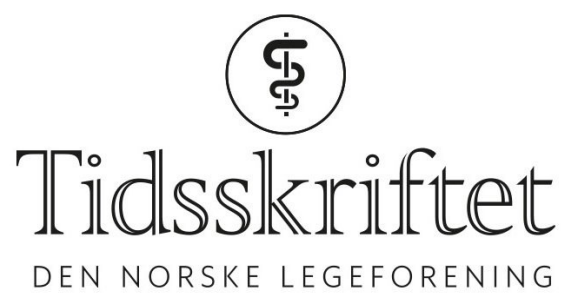

\title{
Rettelse: En somnolent kvinne i 50- årene med akutt sirkulasjonssvikt
}

RETTELSE

JESSICA VILAND

JøRUND LANGØRGEN

ØYSTEIN WENDELBO

Tidsskr Nor Legeforen 2019; 139: 837-41.

I Tidsskriftet nr. 9/2019 på s. 837 og 841 skal forfatterrekkefølgen være:Jessica Viland, Jørund Langørgen, Øystein Wendelbo.

Vi beklager feilen, den er rettet på nett.

Publisert: 20. juni 2019. Tidsskr Nor Legeforen. DOI: 10.4045/tidsskr.19.0363

(C) Tidsskrift for Den norske legeforening 2020. Lastet ned fra tidsskriftet.no 